\title{
Thyroid Function of Pregnant Women and Perinatal Outcomes in North Macedonia
}

\section{Função tireoidiana de mulheres grávidas e resultados perinatais na Macedônia do Norte}

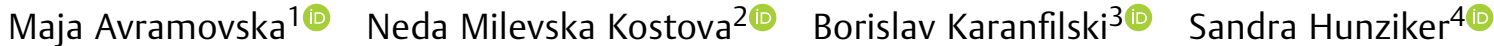

 \\ Marija Hadzi Lega7® Gligor Tofoski ${ }^{6(0)}$ Aleksandar Sikole ${ }^{8(1)}$
}

1 Department of Obstetrics and Gynecology, Clinical Hospital “Dr. Trifun Panovski” - Bitola, Partizanska nn, North Macedonia

${ }^{2}$ Departement Gesundheitswissenschaften und Technologie, Institute for Social Innovation, Skopje, Skopje, North Macedonia

${ }^{3}$ National Committee for lodine Deficiency, Ministry of Health, Skopje, North Macedonia

${ }^{4}$ Laboratory of Human Nutrition, Institute of Food, Nutrition and Health, ETH Zurich, Zurich, Switzerland

5 Institute of Pathophysiology and Nuclear Medicine, Faculty of Medicine, Ss. Cyril and Methodius University Skopje, Skopje, North Macedonia 6 University Clinic of Gynecology and Obstetrics, Faculty of Medicine, Ss. Cyril and Methodius University Skopje, Skopje, North Macedonia
Address for correspondence Maja Avramovska, MD, PhD, Filip Vtori Makedonski 37/4/26, Bitola, North Macedonia

(e-mail: dr.avramovska@gmail.com).

${ }^{7}$ Department for Fetal Screening and Perinatal Medicine, Danat al Emarat Hospital for Women and Children, Abu Dhabi, Emirate of Abu Dhabi

${ }^{8}$ Department of Nephrology, University Clinic of Nephrology, Faculty of Medicine, Ss. Cyril and Methodius University Skopje, Skopje, North Macedonia

Rev Bras Ginecol Obstet 2021;43(10):736-742.

\section{Abstract \\ Keywords \\ - thyroid stimulating hormone \\ - total thyroxine \\ - thyroglobulin \\ - perinatal outcomes \\ - low birth weight}

Objective Thyroid diseases are the second most common endocrine disorders in the reproductive period of women. They can be associated with intrauterine growth restriction (IUGR), preterm delivery, low Apgar score, low birthweight (LBW) or fetal death. The aim of the present study is to explore thyroid dysfunction and its relationship with some poor perinatal outcomes (Apgar Score, low birthweight, and preterm delivery).

Methods Dried blood spot samples from 358 healthy pregnant women were analyzed for thyroid stimulating hormone (TSH), total thyroxine (TT4), and thyroglobulin (Tg). Neonatal data were collected upon delivery. Four groups were formed based on thyroid function tests (TFTs). Results Of the 358 tested women, 218 (60.72\%) were euthyroid. Isolated hypothyroxinemia was present in 132 women (36.76\%), subclinical hyperthyroidism in 7 women (1.94\%), and overt hypothyroidism in $1(0.28 \%)$. The perinatal outcomes IUGR $(p=0.028)$ and Apgar score 1 minute $(p=0.015)$ were significantly different between thyroid function test [TFT]-distinct groups. In the multiple regression analysis, TT4 showed a statistically significant inverse predictive impact on LBW $(p<0.0001)$, but a positive impact of $\mathrm{Tg}$ on LBW $(p=0.0351)$.

Conclusion Thyroid hormones alone do not have a direct impact on neonatal outcomes, but the percentage of their participation in the total process cannot be received

December 4, 2020

accepted

August 9, 2021
DOI https://doi.org/

$10.1055 / \mathrm{s}-0041-1736172$. ISSN 0100-7203. (c) 2021. Federação Brasileira de Ginecologia e Obstetrícia. All rights reserved.

This is an open access article published by Thieme under the terms of the Creative Commons Attribution License, permitting unrestricted use, distribution, and reproduction so long as the original work is properly cited. (https://creativecommons.org/licenses/by/4.0/)

Thieme Revinter Publicações Ltda., Rua do Matoso 170, Rio de Janeiro, RJ, CEP 20270-135, Brazil 


\section{Resumo}

Palavras-chave
- hormônio
estimulante da
tireoide
- tiroxina total
- tireoglobulina
- resultados perinatais
- baixo peso de
nascimento

neglected. Based on the regression analysis, we can conclude that TT4 and Tg can be used as predictors of neonatal outcome, expressed through birthweight and Apgar score. The present study aims to contribute to determine whether a test for thyroid status should become routine screening during pregnancy.

Objetivo As doenças da tireoide são as segundas doenças endócrinas mais comuns no período reprodutivo das mulheres. Elas podem estar associadas à restrição de crescimento intrauterino (RCIU), parto prematuro, baixo índice de Apgar, baixo peso ao nascer (BPN) ou morte fetal. O objetivo do presente estudo é explorar a disfunção tireoidiana e sua relação com alguns resultados perinatais insatisfatórios (índice de Apgar, baixo peso ao nascer e parto prematuro).

Métodos Amostras secas de sangue em 358 gestantes saudáveis foram analisadas para hormônio estimulador da tireoide (TSH), tiroxina total (TT4) e tireoglobulina (Tg). Os dados neonatais foram coletados no momento do parto. Quatro grupos foram formados com base em testes de função tireoidiana (TFT).

Resultados Das 358 mulheres testadas, 218 (60,72\%) eram eutireoidianas. Hipotiroxinemia isolada estava presente em 132 mulheres (36,76\%), hipertireoidismo subclínico em 7 mulheres (1,94\%) e hipotireoidismo evidente em $1(0,28 \%)$. Os resultados perinatais $\operatorname{RCIU}(p=0,028)$ e índice de Apgar de 1 minuto $(p=0,015)$ foram significativamente diferentes entre os grupos distintos de TFT. Na análise de regressão múltipla, TT4 mostrou impacto preditivo inverso estatisticamente significativo no BPN $(p<0,0001)$, mas impacto positivo da Tg no BPN $(p=0,0351)$.

Conclusão Isoladamente, os hormônios tireoidianos não têm impacto direto no desfecho neonatal, mas o percentual de sua participação no processo total não pode ser desprezado. Com base na análise de regressão, podemos concluir que TT4 e Tg podem ser usados como preditores do resultado neonatal, expressos por meio do peso ao nascer e do índice de Apgar. O presente estudo tem como objetivo contribuir para que um teste para verificar o estado da tireoide deva se tornar um rastreamento de rotina durante a gravidez.

\section{Introduction}

Thyroid diseases are the second most common endocrine disorders affecting women in the reproductive period. ${ }^{1}$ Early diagnosis and treatment of thyroid diseases before and during pregnancy is important for maintaining the health of the mother and the baby. ${ }^{2}$ The maternal thyroid gland undergoes physiological changes during pregnancy, including increased thyroid gland vascularity, increased iodine clearance and fluctuation in thyroxine metabolism, which may impair the maternal-fetal transfer of thyroxine despite optimal thyroid status. ${ }^{3}$

Hypothyroidism is relatively uncommon in pregnancy, occurring in between 2 and $3 \%$ of pregnant women, mainly as subclinical form. ${ }^{1}$ Hyperthyroidism in pregnancy, also with very low prevalence ranging between $0.1 \%$ and $1 \%,{ }^{4}$ has been associated with intrauterine growth restriction (IUGR) and low birthweight (LBW). ${ }^{5}$ The study of the Consortium on Safe Labor found that neonates of women with hyperthyroidism were more likely to need resuscitation in the delivery room and neonatal intensive care unit (NICU) admission. Also, they had an 1.6- to 2.0-fold odds of respiratory distress syndrome, transient tachypnea, apnea, sepsis, as well as increased odds of cardiomyopathy, retinopathy of prematurity, and neonatal thyroid disease. $^{5}$

Isolated maternal hypothyroxinemia has been reported in $\sim 1.3 \%$ of pregnant women; however, its incidence can be as high as $25.4 \%{ }^{6}$ An American study of 17,298 women examined the association between maternal isolated hypothyroxinemia and adverse neonatal outcomes, including LBW, Apgar score $<3$, and fetal or neonatal mortality. ${ }^{7}$ The same study suggested that preterm delivery may be associated with maternal hypothyroxinemia, characterizing the condition as detrimental during pregnancy. ${ }^{7}$

According to the guideline of the American Thyroid Association (ATA) for the diagnosis and management of thyroid disease during pregnancy and the postpartum period, ${ }^{8,9}$ the reference values for thyroid stimulating hormone (TSH) and total thyroxine (TT4) range from 0.1 to $3.7 \mathrm{mIU} / \mathrm{L}$ and 65/97.5$165-247.5 \mathrm{nmol} / \mathrm{L}$, respectively. Based on the above, the study population was categorized into four groups.

The largest decrease in TSH is observed during the $1^{\text {st }}$ trimester because of elevated levels of serum hCG directly 
stimulating the TSH receptor, therefore increasing thyroid hormone production. ${ }^{8}$ Consequently, serum TSH and its reference range gradually rise in the $2^{\text {nd }}$ and $3^{\text {rd }}$ trimesters but are still lower than in nonpregnant women.

The aim of our study is 2-fold: first, to examine the correlation between thyroid function tests (TFTs) and neonatal outcome; and second, to evaluate the predictive potential of TSH, TT4 and Tg on delivery and some of the perinatal outcomes (Apgar Score and low birth weight).

\section{Methods}

The present prospective study included 358 healthy pregnant women without known thyroid disorders. For recruitment, the following inclusion criteria were adopted: singleton pregnancy at any gestational age, with the following exclusion criteria: no previous history of thyroid disease or treatment with any thyroid-related therapy, cigarette smoking, and no history of other chronic diseases, in particular diabetes mellitus or hypertension, and any fetal anomaly diagnosed with amniocentesis or ultrasound. Pregnant women were divided into 3 subgroups depending on the gestational age at the time of recruitment: $1^{\text {st }}$ trimester (up to the $12^{\text {th }}$ gestation week [g.w.], second trimester (between the $12^{\text {th }}$ and $28^{\text {th }}$ g.w.), and $3^{\text {rd }}$ trimester $(29$ g.w. to the end of pregnancy).

Participant recruitment and collection of blood samples were performed between April and July 2017. Data on maternal age, weight and height, gestational age at the time of recruitment, as well as eligibility check against exclusion criteria, were collected using a recruitment questionnaire.

Dried blood spot (DBS) samples were collected upon recruitment onto filter paper cards using the standard lancet finger prick method. The samples were dried for 24 hours and stored at $-20^{\circ} \mathrm{C}$. The TSH and TT4 levels were analyzed with a time-resolved fluoroimmunoassay method (GSP 2021-0010; PerkinElmer, Turku, Finland) at the University Children's Hospital, Zurich, Switzerland. The Tg concentration was assessed using a DBS Tg sandwich enzyme-linked immunosorbent assay ${ }^{10}$ at Eidgenössische Technische Hochschule Zürich (ETH Zurich).

Postpartum data was retrieved for each of the labored women from their medical histories. Birthweight and birth length were measured by the midwife attending the birth, while condition of the newborn after delivery and Apgar scores were determined by the neonatologist. In addition, obstetric history, gestational age at the time of birth, as well as the way of birth were noted in the medical history.

Intrauterine growth restriction (IUGR) was defined as birthweight $<10^{\text {th }}$ percentile for the gestational age. Low birthweight (LBW) was defined as weight $\leq 2,500 \mathrm{~g}$, regardless of the gestational age. ${ }^{11}$ Preterm delivery was defined as delivery before 37 completed g.ws.. Low Apgar score was considered if Apgar score at 1 minute was $<7 . .^{12}$

All participants signed an informed consent form after reading the project information sheet, and the ethics approval for the study was obtained from the Etic Committee at Medical Faculty - Skopje, Ss. Cyril and Methodius University - Skopje at its XVI session on January 24, 2019, with $\mathrm{N}^{*} 03-242 / 3$.

Data analyses were performed using MedCalc Statistical Software version 19.1.3 (MedCalc Software, Ostend, Belgium). Continuous variables were presented as mean \pm standard deviation (SD), median (interquartile range [IQR]) (when the frequency distribution for our data was skewed) and percentages (\%). One-way analysis of variance (ANOVA) was used to test the difference between the means of the six subgroups. Prior to the ANOVA test, the Levene test for equality of variances was performed. We applied a logarithmic transformation if the Levene test was positive $(p<0.05)$. Multiple backward regression analysis was used to show predictable values of independent variables (TT4 and Tg as predictors) on the dependent variable (LBW).

\section{Results}

In total, 358 women were included in the analysis. The mean maternal age was $29.27 \pm 5.5$ years old (range: 25 to 33 years old), their BMI was overweight, preobesity state according to the World Health Organization (WHO) classification ${ }^{13}$ $\left(27.12 \pm 4.4 \mathrm{~kg} / \mathrm{m}^{2}\right.$; range: $\left.23.44-29.63 \mathrm{~kg} / \mathrm{m}^{2}\right)$, delivered approximately at $38.43 \pm 2.54$ g.ws. Of the total sample, 64 women were classified at the $1^{\text {st }}$ trimester according to g.w. $(17.82 \%), 100$ were in the $2^{\text {nd }}(27.85 \%)$, and 194 were in the $3^{\text {rd }}$ trimester $(54.03 \%)$ ( - Table 1 ). The median (IQR) TSH of the women in the $1^{\text {st }}$ trimester did not deviate from the reference range $(0.4 \mathrm{mIU} / \mathrm{mL}$; range $0.3 \mathrm{mIU} / \mathrm{mL})$, whereas the TT4 values of only 2 pregnant women $(3.12 \%)$ deviated from it. In the $2^{\text {nd }}$ trimester, from all the cohort, the median TSH was within the reference values $(0.4 \mathrm{mIU} / \mathrm{mL}$; range 1.1 $\mathrm{mIU} / \mathrm{L})$, while the TT4 values of 31 pregnant women (31\%) deviated from the reference range. In the $3^{\text {rd }}$ trimester, the median TSH of $0.56 \mathrm{mIU} / \mathrm{L}$; (range $0.4 \mathrm{mIU} / \mathrm{L}$ ) did not deviate

Table 1 Demographic and clinical characteristics of the study population at recruitment

\begin{tabular}{lll}
\hline Demographic values & $\boldsymbol{n}$ & \% of total \\
\hline $1^{\text {st }}$ trimester & 64 & $17.82 \%$ \\
$2^{\text {nd }}$ trimester & 100 & $27.85 \%$ \\
$3^{\text {rd }}$ trimester & 194 & $54.03 \%$ \\
& Mean \pm SD & $\begin{array}{l}25^{\text {th }}-75^{\text {th }} \mathrm{P} \\
(\text { min }- \text { max })\end{array}$ \\
& $29.27 \pm 5.5$ & $25-33$ \\
Age (years old) & $27.14 \pm 4.7$ & $23.44-29.63$ \\
BMI $\left(\mathrm{kg} / \mathrm{m}^{2}\right)$ & $38.43 \pm 2.54$ & $37.7-40.0$ \\
Gestational week at birth & Normal & Range \\
Thyroid function values & $0.54 \pm 0.33$ & $0.3-0.7$ \\
TSH $(\mathrm{mU} / \mathrm{L})$ & $103.92 \pm 28.7$ & $24-195.2$ \\
TT4 $(\mathrm{nmol} / \mathrm{L})$ & $11.6 \pm 9.01$ & $5.53-15.49$ \\
$\mathrm{Tg}(\mu \mathrm{g} / \mathrm{L})$ &
\end{tabular}

Abbreviations: BMI, body mass index; SD, standard deviation; Tg, thyroglobulin; TSH, thyroid stimulating hormone; TT4, total thyroxine. The results are expressed as median (interquartile range) or mean \pm SD. 
Table 2 Categorization of pregnant women based on gestational age and TFT

\begin{tabular}{|c|c|c|c|}
\hline Group & TSH level & TT4 level & $\begin{array}{l}\text { No. (\%) of pregnant } \\
\text { women in the group }\end{array}$ \\
\hline 1. Normal thyroid function & $\begin{array}{l}\text { normal } \\
\text { (0.1 to } 3.7 \mathrm{mlU} / \mathrm{L})\end{array}$ & $\begin{array}{l}\text { normal, } \\
\text { slightly increased }\end{array}$ & $218(60.72 \%)$ \\
\hline 2. Isolated hypo thyroxinemia & $\begin{array}{l}\text { normal } \\
(0.1 \text { to } 3.7 \mathrm{mlU} / \mathrm{L})\end{array}$ & depressed & $132(36.76 \%)$ \\
\hline 3. Subclinical hyperthyroidism & suppressed (<0.1 mlU/L) & normal & $7(1.94 \%)$ \\
\hline 4. Subclinical hypothyroidism & elevated ( 3 to $10 \mathrm{mIU} / \mathrm{L}$ ) & normal & $0(0.0 \%)$ \\
\hline 5. Overt hypothyroidism & elevated (> $3.7 \mathrm{mIU} / \mathrm{L})$ & $\begin{array}{l}\text { low }(\text { for } \mathrm{TSH}<10 \mathrm{mIU} / \mathrm{L} \text { ) } \\
\text { any level }(\text { for } \mathrm{TSH} \geq 10 \mathrm{mIU} / \mathrm{L}\end{array}$ & $1(0.27 \%)$ \\
\hline 6. Overt hyperthyroidism & suppressed $(<0.1 \mathrm{mIU} / \mathrm{L})$ & high (or irrelevant) & $0(0.0 \%)$ \\
\hline
\end{tabular}

Abbreviation: TSH, thyroid stimulating hormone.

from reference range; however, the TT4 values of 54 (27.83\%) pregnant women deviated from the reference range. - Table 1 summarizes the clinical and demographic characteristics of the study population at the time of recruitment.

Of the cohort of 358 tested women, 193 pregnancies were terminated with normal vaginal delivery (53.91\%), while 165 women underwent cesarean section (46.08\%). From all the births, 41 delivered prematurely (before the $37^{\text {th }}$ g.w.) corresponding to $11.45 \%$, and only 21 infants had an Apgar score value at 1 minute $<7$ (5.86\%). Low birthweight was noted in 47 cases (13.12\%). When we categorized the pregnant women according to their gestational age and TFT, we noticed that, from the total of the group, 218 mothers (60.72\%) were euthyroid. Isolated hypothyroxinemia was present in 132 women (36.76\%), subclinical hyperthyroidism in 7 women (1.94\%), overt hypothyroidism in $1(0.28 \%)$, and no cases $(0 \%)$ with subclinical hypothyroidism or overt hyperthyroidism (-Table 2).

- Table 3 shows the way of birth in each group. A total of $58.25 \%$ of the pregnant women with normal thyroid function, $46.21 \%$ of the isolated hypothyroxinemia group, and $71.42 \%$ of the subclinical hyperthyroidism group had normal spontaneous delivery. Also, the fetal outcome in each group is shown in - Table 3. Adverse fetal outcome in isolated hypothyroxinemia included preterm delivery (9.84 versus 0 versus $12.84 \%$ ), IUGR (2.27 versus 0 versus $4.12 \%$ ), and LBW (12.87 versus 14.28 versus $13.30 \%$ ) as compared with the group of subclinical hyperthyroidism and normal thyroid function group, consequently. Apgar score (1 minute) $<7$ was seen in the group of subclinical hyperthyroidism in $28.57 \%$ of the cases, compared with the group of normal thyroid function, which appears with 5.96\%. and the

Table 3 Mode of delivery and fetal outcomes in different groups

\begin{tabular}{|c|c|c|c|c|c|c|}
\hline Groups & 1 & 2 & 3 & 4 & & \\
\hline Mode of delivery & $\begin{array}{l}\text { Normal } \\
\text { thyroid function } \\
(n=218)\end{array}$ & $\begin{array}{l}\text { Isolated } \\
\text { hypothyroxinemia } \\
(n=132)\end{array}$ & $\begin{array}{l}\text { Subclinical } \\
\text { hyperthyroidism } \\
(n=7)\end{array}$ & $\begin{array}{l}\text { Overt } \\
\text { hypothyroidism } \\
(n=1)\end{array}$ & $\mathrm{F}$ & p-value \\
\hline Normal spontaneous delivery & $127(58.25)$ & $61(46.21)$ & $5(71.42)$ & 0 & 2.6975 & 0.068 \\
\hline CS total & $91(41.74)$ & $71(53.78)$ & $2(28.57)$ & 1 & & \\
\hline - CS for fetal distress & $28(30.76)$ & $10(7.57)$ & $1(14.28)$ & 1 & 1.1334 & 0.323 \\
\hline $\begin{array}{l}\text { - CS for dystotia/ } \\
\text { dysproprtion }\end{array}$ & $25(27.47)$ & $11(8.33)$ & $1(14.28)$ & 0 & 4.175 & 0.024 \\
\hline \multicolumn{7}{|l|}{ Fetal outcomes } \\
\hline Preterm births & $28(12.84)$ & $13(9.84)$ & 0 & 0 & 0.804 & 0.448 \\
\hline IUGR & $9(4.12)$ & $3(2.27)$ & 0 & 0 & 3.594 & 0.028 \\
\hline LBW & $29(13.30)$ & $17(12.87)$ & $1(14.28)$ & 0 & 0.517 & 0.597 \\
\hline Apgar score (1 minute) $<7$ & $13(5.96)$ & $6(4.54)$ & $2(28.57)$ & 1 & 4.252 & 0.018 \\
\hline \multicolumn{7}{|l|}{ Mother characteristics } \\
\hline Median age (years old) & 29 & 29 & 32 & 26 & 1.299 & 0.274 \\
\hline Median BMI, kg/m² & 26.44 & 27.43 & 23.23 & 27.12 & 4.091 & 0.018 \\
\hline
\end{tabular}

Abbreviations: BMI, body mass index; CS, cesarean section; IUGR, intrauterine growth restriction; LBW, low birthweight. 
Table 4 Multiple backward regression analysis of low birthweight according to thyroid status categorization groups

\begin{tabular}{|c|c|c|c|c|c|c|c|}
\hline Dependent $Y$ & LBW & & & & & & \\
\hline \multicolumn{8}{|l|}{ Regression Equation } \\
\hline Independent variables & $\beta$ st coefficient & Std. Error & $\mathbf{t}$ & $p$-value & $r_{\text {partial }}$ & $r_{\text {semipartial }}$ & $\exp (\beta s t)$ \\
\hline (Constant) & 2.5225 & & & & & & \\
\hline TT4 & -0.01124 & 0.0009484 & -11.854 & $<0.0001$ & -0.5391 & 0.5388 & 0.98767 \\
\hline $\mathrm{Tg}$ & 0.006294 & 0.002975 & 2.116 & 0.0351 & 0.1135 & 0.09616 & 1.00631 \\
\hline Significance level & & & & & & & $p<0.0001$ \\
\hline
\end{tabular}

Abbreviations: $\beta$ st, $\beta$ standardized; LBW, low birthweight; Std, standard; Tg, thyroglobulin; TT4=total thyroxine.

isolated hypothyroxinemia group, with $4.54 \%$. The median BMI was $26.44 \mathrm{~kg} / \mathrm{m}^{2}$ for women with normal thyroid function, $27.96 \pm 5.05 \mathrm{~kg} / \mathrm{m}^{2}$ for women with isolated hypothyroxinemia, and $23.23 \mathrm{~kg} / \mathrm{m}^{2}$ for those with subclinical hyperthyroidism $(p=0.018)$. Obese women had depressed TT4 range and were prone to hypothyroxinemia. Substantial differences between the four groups in accordance with their impact on the neonatal outcome are presented by ANOVA results: F-ratio (F) and p-value of significance $(p)$ are shown in -Table 3. The statistical significance of each group differs according to certain variables shown: Apgar score (1 minute) $(\mathrm{F}=4.252 ; p=0.015)$, IUGR $(\mathrm{F}=3.594 ; p=0.028)$, and mean BMI $(F=4.091 ; p=0.018)$. A greater $F$-ratio value and $A$ smaller $p$ mean a higher difference between the groups according to outcomes, according to thyroid status that defines groups.

The results of the Levene test show significance only for Apgar score (1 minute). Levene statistic ( $L S=7.897)$ and p-value $(p<0.001)$. The Levene test for IUGR (LS $=1.643$; $p=0.179)$ and BMI ( $L S=1.3 ; p=0.274)$ do not show statistical significance. Assessments (standardized coefficient $\beta$ [ $\beta s t$ ], standard error of $\beta$ st [Std. Error], t, p-value, partial $r$ $\left[r_{\text {partial }}\right]$, semipartial $r\left[r_{\text {semipartial }}\right]$, and $\left.\exp [\beta s t]\right)$ of the dependent predictor LBW or determinants (TT4 and Tg) for increasing the incidence of LBW in TFT-categorized groups after backward multiple regression analysis are shown in -Table 4.

Groups 3 and 4 were excluded from the regression analysis due to small group size. The p-values followed the order of statistical significance: TT4 $(<0.0001)$ and $\mathrm{Tg}$ (0.0351). Due to the regression model criterion (remove variable if $p>0.5$ ), TSH was not included in the regression analysis. There was an inverse correlation (negative $\beta s t$ coefficient; $\beta s t=-0.01124$ ) between TT4 and LBW, and a positive correlation (positive $\beta s t=0.006294$ ) between $\mathrm{Tg}$ and LBW. The regression parameter exp ( $\beta \mathrm{st}$ ) for TT4 $(1.012484=1 / 0.98767)$ signified that with each increase of $1 \mathrm{unit}(\mathrm{nmol} / \mathrm{L})$ in TT4, the LBW score decreased by $1.01248 \mathrm{~g}$. The regression parameter exp ( $\beta s t)$ for $\mathrm{Tg}$ (1.00631) signified that with each increase of $1 \mathrm{unit}(\mu \mathrm{g} / \mathrm{L})$ in $\mathrm{Tg}$, the LBW score increased by $1.00631 \mathrm{~g}$. The coefficient of determination $\mathrm{R}^{2}$ (0.2914) and the multiple correlation coefficients (0.5398) showed that $29.14 \%$ from LBW was dependent on TT4 and Tg as the predictors. Only $29.14 \%$ of the changes in LBW were a result of TT4 changes (accompanied by Tg changes), and the remaining from the total variability between them were not explained (70.86\% of LBW were dependent on other factors, which were not covered with the regression model. Partial coefficient of regression $\beta$ st for Tg affects the LBW, because there is a simple linear relationship between Tg and LBW and it can be used for predicting. In addition, TT4 is in a simple linear relationship with LBW, and it can also be used for predicting LBW.

\section{Discussion}

Attention to thyroid dysfunction during pregnancy has increased in the past decade, particularly in the area of subclinical thyroid dysfunction, as thyroid disease is the second most common endocrine disorder complicating pregnancy. ${ }^{14}$ We examined the thyroid function through TSH and TT4 and its relationship with perinatal outcomes in 358 healthy pregnant women divided in subgroups created by ATA guidelines.

We revealed that thyroid dysfunction during pregnancy was associated with preterm delivery, low Apgar score and low birth weight $(<2,500 \mathrm{~g})$, even in the forms of isolated hypothyroxinemia. The study of Saki et al. ${ }^{15}$ showed that both hyperthyroidism and hypothyroidism are associated with IUGR, contrary to our results, in which isolated hypothyroxinemia was connected with IUGR. They found that hypothyroidism was associated with IUGR $(p=0.017)$ and low Apgar score in the first minute $(p=0.04)$; thus, the risk for IUGR was increased by 2.2 times, and the low Apgar score increased the risk by 1.95 times. Intergroup comparison in our study showed statistically significant differences with respect of IUGR ( $p=0.028)$ and Apgar score [ 1 minute $)<7]$ $(p=0.018)$, results similar and close to the above-mentioned studies.

Clinical hypothyroidism also showed a statistically significant correlation with premature labor $(p=0.045)$ in the study by Saki et al. ${ }^{15}$ According to Davis et al., ${ }^{16}$ premature labor occurred in $44 \%$ of pregnant women diagnosed with hypothyroidism and in $17 \%$ of pregnant women with subclinical hypothyroidism, which is similar to our results for preterm births ( $18 \%$ of women with subclinical hypothyroidism labored prematurely).

Millar et al. ${ }^{17}$ also reviewed pregnancy outcomes in 181 women with hyperthyroidism and demonstrated that uncontrolled hyperthyroidism was associated with a 9-fold 
higher LBW rate compared with the control population, which is not different from our study results. We found that TT4 $(p<0.0001)$ and $\operatorname{Tg}(p=0.0351)$ have a simple linear relationship with LBW and can be used for predicting it. Based on the multiple correlation coefficient in our study, it is calculated that $53.98 \%$ from LBW was dependent on TT4 and $\mathrm{Tg}$ as the predictors.

In our study, isolated hypothyroxinemia was associated with increased risk of preterm delivery (3.62\% of all pregnancies) and with increased rate of cesarean section delivery (51.58\%). Also, LBW $(<2,500 \mathrm{~g})$ was found in $11.90 \%$ of the newborns and lower Apgar score (1 minute) $<7$ (2.38\%). Subclinical hyperthyroidism had association with increased risk of preterm delivery (18\%), as well as low Apgar score at the $1^{\text {st }}$ minute (25\%) and $\mathrm{LBW}<2,500 \mathrm{~g}(25 \%)$.

According to Davis et al., ${ }^{16}$ perinatal mortality and morbidity were also increased due to placental abruption (19\%), as well as to postpartum hemorrhage and anemia (19\%), with consequent LBW (31\%) or even fetal death (12\%). Leung at al. ${ }^{18}$ found that the pregnancies with overt hypothyroidism had significant increase in the incidence of LBW of the neonates $(<2,500 \mathrm{~g})$ compared with controls. Others found no association between thyroid hormonal status or thyroid antibody positivity and preterm delivery or other obstetrical complications, like in the study of Lejeune et al. ${ }^{19}$ In a study of 233 pregnant women with isolated hypothyroxinemia, Casey et al. ${ }^{20}$ reported no increased adverse perinatal outcomes associated with the condition.

The present study has limitations. First, although the results of the study were statistically significant for some of the analyses, the number of women with thyroid dysfunction was limited, especially in groups with subclinical hyperthyroidism and overt hypothyroidism. Second, neither thyroid peroxidase antibodies (TPOAb), nor thyroglobulin antibodies $(\mathrm{TgAb})$ were evaluated by us, which are also connected to negative neonatal outcomes. In the future, a bigger cohort plus TPOAb and TgAb evaluation is a logical next step.

\section{Conclusion}

Thyroid hormones alone do not have a direct impact on neonatal outcome. However, even if it was small, the percentage of their participation in the total process that affect the final outcome cannot be neglected. Based on the regression analysis, we can conclude that TT 4 and $\mathrm{Tg}$ can be used as determinants for predicting the neonatal outcome, expressed through birthweight and Apgar score. These results are similar to the data that had been evaluated over the past 10 years, although there are still ongoing studies trying to clarify whether maternal subclinical hyperthyroidism and isolated hypothyroxinemia in pregnancy are associated with adverse outcomes. The present study aims to contribute to the scientific debate as to whether a test for thyroid status should become routine screening during pregnancy.

\section{Contributions}

All authors participated in the concept and design of the present study; in the analysis and interpretation of data; in the elaboration of the draft or in the revision of the manuscript; and they have approved the manuscript as submitted. All authors are responsible for the reported research.

\section{Conflict of Interests}

The authors have no conflict of interests to declare.

\section{Acknowledgments}

The present study is supported by funding from the European Union's Horizon 2020 research and innovation program under Grant agreement no.634453. It is part of International EUthyroid project task 3.3.

\section{References}

1 Negro R, Mestman JH. Thyroid disease in pregnancy. Best Pract Res Clin Endocrinol Metab. 2011;25(06):927-943. Doi: 10.1016/j. beem.2011.07.010

2 Dulek H, Vural F, Aka N, Zengin S. The prevalence of thyroid dysfunction and its relationship with perinatal outcomes in pregnant women in the third trimester. North Clin Istanb. 2019;6(03):267-272. Doi: 10.14744/nci.2018.51422

3 Sreelatha S, Nadagoudar S, Asha Devi L. The study of maternal and fetal outcome in pregnant women with thyroid disorders. Int J Reprod Contracept Obstet Gynecol. 2017;6(08):3507-3513. Doi: 10.18203/2320-1770.ijrcog20173473

4 Moleti M, Di Mauro M, Sturniolo G, Russo M, Vermiglio F. Hyperthyroidism in the pregnant woman: Maternal and fetal aspects. J Clin Transl Endocrinol. 2019;16:100190. Doi: 10.1016/j. jcte.2019.100190

5 Männistö T, Mendola P, Reddy U, Laughon SK. Neonatal outcomes and birth weight in pregnancies complicated by maternal thyroid disease. Am J Epidemiol. 2013;178(05):731-740. Doi: 10.1093/ aje/kwt031

6 López-Muñoz E, Mateos-Sánchez L, Mejía-Terrazas GE, BedwellCordero SE. Hypothyroidism and isolated hypothyroxinemia in pregnancy, from physiology to the clinic. Taiwan J Obstet Gynecol. 2019;58(06):757-763. Doi: 10.1016/j.tjog.2019.09.005

7 Casey BM, Dashe JS, Spong CY, McIntire DD, Leveno KJ, Cunningham GF. Perinatal significance of isolated maternal hypothyroxinemia identified in the first half of pregnancy. Obstet Gynecol. 2007;109 (05):1129-1135. Doi: 10.1097/01.AOG.0000262054.03531.24

8 Stagnaro-Green A, Abalovich M, Alexander E, Alexander E, Azizi F, Mestman J, et al; American Thyroid Association Taskforce on Thyroid Disease During Pregnancy and Postpartum. Guidelines of the American Thyroid Association for the diagnosis and management of thyroid disease during pregnancy and postpartum. Thyroid. 2011;21(10):1081-1125. Doi: 10.1089/thy.2011.0087

9 Alexander EK, Pearce EN, Brent GA, Brown RS, Chen H, Dosiou C, et al. 2017 Guidelines of the American Thyroid Association for the diagnosis and management of thyroid disease during pregnancy and the postpartum. Thyroid. 2017;27(03):315-389. Doi: 10.1089/thy.2016.0457

10 Stinca S, Andersson M, Erhardt J, Zimmermann MB. Development and validation of a new low-cost enzyme-linked immunoassay for serum and dried blood spot thyroglobulin. Thyroid. 2015;25(12): 1297-1305. Doi: 10.1089/thy.2015.0428

11 World Health Organization. International statistical classification of diseases and related health problems. 10th ed. Geneva: WHO; 2009 
742 Thyroid Function of Pregnant Women and Perinatal Outcomes in North Macedonia Avramovska et al.

12 Committee on Obstetric Practice American Academy of Pediatrics. Committee Opinion No. 644: The Apgar Score. Obstet Gynecol. 2015;126(04):e52-e55. Doi: 10.1097/AOG.0000000000001108

13 World Health Organization. Obesity: preventing and managing the global epidemic. Report of a WHO Consultation. Geneva: World Health Organization; 2000 (WHO Technical Report Series; 894).

14 Sushma K Sannaboraiah, Ashwini Halebid Ramaswamy, Safiya Shaikh. Thyroid disorders during pregnancy and anesthetic considerations. Anaesth Pain Intensive Care. 2014;18(03):302-307. Doi: 10.35975/apic.v0i0.832

15 Saki F, Dabbaghmanesh MH, Ghaemi SZ, Forouhari S, Ranjbar Omrani G, Bakhshayeshkaram M. Thyroid function in pregnancy and its influences on maternal and fetal outcomes. Int J Endocrinol Metab. 2014;12(04):e19378. Doi: 10.5812/ijem.19378

16 Davis LE, Leveno KJ, Cunningham FG. Hypothyroidism complicating pregnancy. Obstet Gynecol. 1988;72(01):108-112
17 Millar LK, Wing DA, Leung AS, Koonings PP, Montoro MN, Mestman JH. Low birth weight and preeclampsia in pregnancies complicated by hyperthyroidism. Obstet Gynecol. 1994;84(06): 946-949

18 Leung AS, Millar LK, Koonings PP, Montoro M, Mestman JH. Perinatal outcome in hypothyroid pregnancies. Obstet Gynecol. 1993;81(03):349-353

19 Lejeune B, Grun JP, de Nayer P, Servais G, Glinoer D. Antithyroid antibodies underlying thyroid abnormalities and miscarriage or pregnancy induced hypertension. Br J Obstet Gynaecol. 1993;100 (07):669-672. Doi: 10.1111/j.1471-0528.1993.tb14236.x

20 Casey BM, Dashe JS, Wells CE, McIntire DD, Byrd W, Leveno KJ, et al. Subclinical hypothyroidism and pregnancy outcomes. Obstet Gynecol. 2005;105(02):239-245. Doi: 10.1097/01. AOG.0000152345.99421.22 